\title{
Carpal Bone Fracture
}

National Cancer Institute

\section{Source}

National Cancer Institute. Carpal Bone Fracture. NCI Thesaurus. Code C26777.

A traumatic break in one of the small bones in the wrist. 